\title{
A case of autism with an interstitial deletion on $4 q$ leading to hemizygosity for genes encoding for glutamine and glycine neurotransmitter receptor sub-units (AMPA 2, GLRA3, GLRB) and neuropeptide receptors NPYIR, NPY5R Subhadra Ramanathan, Abigail Woodroffe, Pamela L Flodman, Lee Z Mays, Mona Hanouni, Charlotte B Modahl, Robin Steinberg-Epstein, Maureen E Bocian, M Anne Spence and Moyra Smith*
}

Address: Department of Pediatrics, University of California, Irvine; Irvine, CA, USA

Email: Subhadra Ramanathan - subhs@yahoo.com; Abigail Woodroffe - a_woodroffe@hotmail.com; Pamela L Flodman - pflodman@uci.edu; Lee Z Mays - leezmays@ hotmail.com; Mona Hanouni - mhanouni@uci.edu; Charlotte B Modahl - cmodahl@uci.edu; Robin SteinbergEpstein - rsteinbe@uci.edu; Maureen E Bocian - mebocian@uci.edu; M Anne Spence - maspence@uci.edu; Moyra Smith* - dmsmith@uci.edu * Corresponding author

Published: 16 April 2004

BMC Medical Genetics 2004, 5:10
Received: 21 January 2004

Accepted: 16 April 2004

This article is available from: http://www.biomedcentral.com/I47I-2350/5/10

(C) 2004 Ramanathan et al; licensee BioMed Central Ltd. This is an Open Access article: verbatim copying and redistribution of this article are permitted in all media for any purpose, provided this notice is preserved along with the article's original URL.

\begin{abstract}
Background: Autism is a pervasive developmental disorder characterized by a triad of deficits: qualitative impairments in social interactions, communication deficits, and repetitive and stereotyped patterns of behavior. Although autism is etiologically heterogeneous, family and twin studies have established a definite genetic basis. The inheritance of idiopathic autism is presumed to be complex, with many genes involved; environmental factors are also possibly contributory. The analysis of chromosome abnormalities associated with autism contributes greatly to the identification of autism candidate genes.

Case presentation: We describe a child with autistic disorder and an interstitial deletion on chromosome 4q. This child first presented at 12 months of age with developmental delay and minor dysmorphic features. At 4 years of age a diagnosis of Pervasive Developmental Disorder was made. At II years of age he met diagnostic criteria for autism. Cytogenetic studies revealed a chromosome 4q deletion. The karyotype was 46, XY del 4 (q31.3-q33). Here we report the clinical phenotype of the child and the molecular characterization of the deletion using molecular cytogenetic techniques and analysis of polymorphic markers. These studies revealed a 19 megabase deletion spanning $4 q 32$ to $4 q 34$. Analysis of existing polymorphic markers and new markers developed in this study revealed that the deletion arose on a paternally derived chromosome. To date 33 genes of known or inferred function are deleted as a consequence of the deletion. Among these are the AMPA 2 gene that encodes the glutamate receptor GluR2 sub-unit, GLRA3 and GLRB genes that encode glycine receptor subunits and neuropeptide $Y$ receptor genes NPYIR and NPY5R.

Conclusions: The deletion in this autistic subject serves to highlight specific autism candidate genes. He is hemizygous for AMPA 2, GLRA3, GLRB, NPYIR and NPY5R. GluR2 is the major determinant of AMPA receptor structure. Glutamate receptors maintain structural and functional plasticity of synapses. Neuropeptide $Y$ and its receptors NPYIR and NPY5R play a role in hippocampal learning and memory. Glycine receptors are expressed in very early cortical development. Molecular cytogenetic studies and DNA sequence analysis in other patients with autism will be necessary to confirm that these genes are involved in autism.
\end{abstract}




\section{Background}

Although there is clear evidence from twin studies and from family studies that genetics contributes to the etiology of autism, it is likely that many different genes are involved [1-3]. Identification of autism candidate genes through linkage analysis is hampered by the extreme genetic heterogeneity in autism and by the fact that there are many more sporadic cases of autism than familial cases. In a number of different genetic diseases, structural chromosome changes (deletions, duplications, translocations or inversions) that segregate with the disease phenotype have served to narrow the search for disease determining genes to specific chromosome regions and subsequently to specific candidate genes. Recently there has been substantial progress made in the identification of genes for X-linked mental retardation by molecular genetic investigation of structural chromosome changes, including microdeletions of the $\mathrm{X}$ chromosome. These studies led to identification of candidate genes for mental retardation. Subsequently mutation screening of these candidate genes in subjects without chromosome changes led to definitive identification of genes responsible for Xlinked mental retardation. These studies in mental retardation constitute a paradigm for identification of genes that play a role in autism. Our molecular genetic analysis of the deletion on chromosome $4 \mathrm{q}$ in the patient described here highlights specific autism candidate genes. These genes are of particular interest since they encode receptors for glutamine and glycine neurotransmitter receptors and receptors for neuropeptides $\mathrm{Y}$.

\section{Case presentation}

We report a case of autism in which a chromosome $4 \mathrm{q}$ microdeletion was detected.

\section{Pregnancy and family history}

The patient, AU0052-0201, was born to a 38-year old mother at 42 weeks of gestation. Pregnancy was uneventful. According to the mother, an amniocentesis performed was normal. Delivery was reportedly induced secondary to oligohydramnios. The birth weight was $71 / 2$ pounds (50 $0^{\text {th }}$ percentile); birth length was $20^{\text {" }}$ ( $50^{\text {th }}$ percentile $)$. At birth, metatarsus adductus and calcaneovalgus of the left foot, bilateral $2^{\text {nd }}-3^{\text {rd }}$ toe syndactyly and bilateral cryptorchidism were noted. Family history is non-contributory. The patient is the youngest of three children born to a non-consanguineous Caucasian couple. His elder brother and sister are healthy and developmentally normal.

The patient rolled over at 3-4 months, sat alone by 6 months, stood alone at 15-18 months and walked alone at 20 months. His motor milestones delays were attributed to casting on his left foot for correction of metatarsus adductus.

\section{Dysmorphology evaluation}

Minor dysmorphic features noted at 12 months of age were a nose with a flat, broad base, broad tip, slightly short bridge and slightly anteverted nares, bilateral $5^{\text {th }}$ finger clinodactyly and short $5^{\text {th }}$ metatarsals bilaterally. The patient's head circumference was at $<5^{\text {th }}$ percentile from ages 1 to 12 . However, at 15 years his head circumference was noted to be at the $35^{\text {th }}$ percentile. A neurological exam at age 15 revealed grossly intact cranial nerves. There was no evidence of tics, tremors, or seizures.

\section{Psychosocial assessment}

At age 11 years 10 months, the patient satisfied diagnostic criteria for autistic disorder by DSM-IV criteria [4] in an evaluation using the Autism Diagnostic Observation Schedule- Generic (ADOS-G) Module 2, [5] and the Autism Diagnostic Interview- Revised (ADI-R) [6]. The patient test scores revealed impairments in social interaction and communication and increased repetitive stereotypic behaviors. The patient received a composite score of 59 on the Stanford-Binet Scales of Intelligence, Fourth Edition [7].

\section{Language assessment}

The patient's first word "dada" was uttered at 2 years of age. At 26 months, his mother reported he said few words and uttered 'animal sounds'. The patient communicated through gestures rather than vocalizations. Assessments of language included the Peabody Picture Vocabulary test-III Form A (PPVT-IIIA) [8] and the Preschool Language ScaleThird Edition (PLS-3). The scores from the language testing at 11 years and 10 months revealed that auditory comprehension age was equivalent to 4 years and 6 months, and expressive communication age was equivalent to 3 years and 10 months.

\section{Routine cytogenetic testing}

Karyotype analysis on peripheral blood was carried out at the age of 10 years 11 months. Metaphase chromosomes at 550 band resolution were examined. These studies revealed an interstitial deletion on chromosome 4q. The karyotype was reported as 46, XY del 4 (q31.3-q33). Molecular genetic studies were undertaken to define the limits of the deletion, to determine which genes were deleted in consequence of the deletion and to define the parental origin of the deletion.

\section{Molecular cytogenetic analysis}

White blood cells and cultured lymphoblastoid cell lines from the patient were used to produce slides with spreads of metaphase chromosomes and interphase nuclei. A series of linearly ordered BAC (bacterial artificial chromosome) clones were identified from the Human Genome Resources database at http://www.ncbi.nlm.nih.gov[9] for the region of interest on chromosome $4 \mathrm{q}$. The BAC 
Table I: New microsatellite repeat polymorphisms identified in the 4q32-4q34 region.

\begin{tabular}{lll}
\hline Marker & Primer sequence & Size of most common allele \\
\hline Pdgfcl06 & F- CCC AAG CAG AGT TGA GGG TA & $148-150$ bP \\
$\mathbf{6 1 2 j 1 5}$ & R- TGA TTA ACA CTG AGA TAT TTG GCA TT & $118-122$ bP \\
GluR22488 & F- CAG GGA CCT GTA GTG TTG TGC & 98 bP \\
M6-91472 & R- GGA ACT GAA TTA GGA ACC AGA TAT ACA & \\
& F- GAC TGC CTG CCC CTC TCT & $151-153$ bP \\
& R- CCC TCT CTC CTC TCT CAC TCA & \\
\hline
\end{tabular}

clones span 4 sequenced contigs and cover about $30 \mathrm{Meg}$ abases (Mb) of DNA on chromosome 4 from the 4 q31.3$4 \mathrm{q} 32$ junction to $4 \mathrm{q} 35.2$.

The BAC clones were obtained from Research GeneticsInvitrogen as glycerol stocks and processed according to supplier's protocol. DNA from individual BAC clones was labeled using nick translation and SpectrumGreen dUTP (Vysis TM). Labeled BAC DNA was ethanol precipitated along with human Cot1 DNA to block repetitive sequences. The precipitate was resuspended in hybridization buffer (Vysis). Each clone was then used as a probe in fluorescence in situ hybridization (FISH) experiments on the metaphase chromosomes and interphase nuclei from the patient's peripheral blood lymphocytes and cultured cells. Hybridization and post-hybridization washing of slides was carried out according to the manufacturer's protocols (Vysis). SpectrumOrange dUTP labeled 4q subtelomeric probe was used as a control.

\section{Analysis of polymorphic markers}

A total of 21 microsatellite repeat markers were used to define the proximal and distal breakpoints of the deletion. 17 markers were identified from the Human Genome Resources website at http:// www.ncbi.nlm.nih.gov[9]. Primer sequences were obtained from the Marshfield Clinic database [10]. The heterozygosity of all these markers, except D4S2427, was obtained from the comprehensive genetic map generated from the Centre d'Etude du Polymorphisme Humain (CEPH) database [11]. Only markers with heterozygosity between 0.70 and 0.90 were chosen for the analysis.

Four new polymorphic markers, Pdgfc106, 612J15, GluR22488 and M6-91472 were defined. They were identified by screening DNA sequences available on the Human Genome Resources website for regions of dinucleotide repeats. Sequences flanking the repeats were used to design primers for amplifying the repeat containing segment. Primer sequences were entered into BLAST http:// www.ncbi.nlm.nih.gov/BLAST/[12] to determine that the
DNA sequence of each primer set was unique based on current sequence information and that each primer set identified a single locus. Primer sequences for these markers are documented in Table 1. Pdgfc106 primer sequence starts at nucleotide 106763 in Bac RP11-154F14. Primer sequence for marker 612J15 starts at nucleotide 31423 in Bac RP11-612J15. Primer sequence for marker GluR22488 starts at nucleotide 22488 in Bac RP11392C20. Primer sequence for marker M6-91472 starts at nucleotide 91861 in Bac RP11-368D18.

Primers were ordered from Sigma Genosys with the 5' end of the forward primer fluorescein-labeled. PCR products generated from genomic DNA were electrophoresed on an ABI 377 electrophoresis system with laser detection. The gel peaks representing different alleles were compared to labeled size standards to determine the allele sizes.

Study protocol was approved by the Human Subjects Internal Review Board at University of California, Irvine.

\section{Cytogenetic analysis}

Molecular cytogenetic analysis with the BAC clones in FISH experiments revealed a $19 \mathrm{Mb}$ deletion in the patient on chromosome 4 spanning $4 \mathrm{q} 32$ to $4 \mathrm{q} 34$ (Table 2). Each of the BAC clones used gave a unique signal on chromosome $4 \mathrm{q}$.

\section{Microsatellite analysis}

Table 3 summarizes the data from the markers that were informative in this family. The deletion arose on the paternally derived chromosome as a de novo event. Nonpaternity is unlikely as the patient inherited a paternal allele for all informative markers outside the deleted region and also for markers on other chromosomes (data not shown).

\section{Genes in the deleted region}

The deleted region was examined using the Human Genome Resources website at NCBI [9]. The $19 \mathrm{Mb}$ deletion spans five sequenced contigs with 33 genes for which 
Table 2: AU0052-020I FISH data summary

\begin{tabular}{llll}
\hline Clone ID & Starts at Kilobase & Map Position & Result I \\
\hline RPII-90K3 & 158,030 & $4 q 32$ & $+/+$ \\
RPII-704A20 & 158,520 & $4 q 32$ & $+/-$ \\
RPII-372N22 & 158,730 & $4 q 32-q 33$ & $+/-$ \\
RPII-27HII & 160,207 & $4 q 32$ & $+/-$ \\
RPII-272NI3 & 172,998 & $4 q 33-q 34$ & $+/-$ \\
RPII-79K2 & 178,880 & $4 q 34$ & $+/+$ \\
RPII-I8D7 & 184,260 & $4 q 35$ & $+/+$ \\
RPII-50L2I & 186,770 & $4 q 35$ & $+/+$ \\
RPII-33MII & 188,359 & $4 q 35.2$ & $+/+$ \\
\hline
\end{tabular}

I +/+ Bac Clone signals on both chromosomes +/- Bac Clone signal deleted on one chromosome Map position of clones as of 3/23/04

Table 3: Genotyping of markers on chromosome 4q.

\begin{tabular}{|c|c|c|c|c|c|}
\hline Marker & Father Size (bp)' & Mother Size (bp) & Subject Size (bp) & Distance in $\mathbf{K b}^{2}$ & Conclusion \\
\hline \multirow[t]{2}{*}{ Pdgfc 106} & 148 & 150 & 148 & & Heterozygous \\
\hline & 150 & & 150 & & \\
\hline \multirow[t]{2}{*}{$612 J 15$} & 119 & 121 & 123 & & Deletion \\
\hline & & 123 & & & \\
\hline \multirow[t]{2}{*}{ D4SI629 } & 146 & 146 & 150 & $|58,9| 4$ & Deletion \\
\hline & & 150 & & & \\
\hline \multirow[t]{2}{*}{ D4S24II } & 213 & 209 & 209 & 160,016 & Deletion \\
\hline & 218 & & & & \\
\hline \multirow[t]{2}{*}{ D4S2982 } & 186 & 179 & 179 & 161,672 & Deletion \\
\hline & 194 & 198 & & & \\
\hline \multirow[t]{2}{*}{ D4S2368 } & 322 & 314 & 314 & 169,412 & Deletion \\
\hline & & 318 & & & \\
\hline \multirow[t]{2}{*}{ D4S3028 } & 234 & 224 & 227 & 177,286 & Deletion \\
\hline & & 227 & & & \\
\hline \multirow[t]{2}{*}{ M6-9|472 } & $|5|$ & $15 \mid$ & $15 \mid$ & & Heterozygous \\
\hline & & 153 & 153 & & \\
\hline \multirow[t]{2}{*}{ D4S2427 } & 300 & 296 & 296 & 178,449 & Heterozygous \\
\hline & & 300 & 300 & & \\
\hline \multirow[t]{2}{*}{ D4SI552 } & 193 & 183 & 193 & 179,526 & Heterozygous \\
\hline & & 195 & 195 & & \\
\hline \multirow[t]{2}{*}{ D4S2924 } & 230 & 234 & 230 & $|87| 48$, & Heterozygous \\
\hline & 232 & 236 & 236 & & \\
\hline
\end{tabular}

I basepairs ${ }^{2}$ Kilobases Map position of polymorphic markers in NCBI as of $\mathrm{I} / 19 / 04$

the function of the protein product is known or inferred. These contigs also contain 26 sequences that express hypothetical proteins, 9 proteins of unknown function with homology to previously identified proteins and 12 Expressed Sequence Tags (ESTs). Among the 33 genes of known or inferred function, 13 are expressed in the brain. Genes that may be considered to be candidate genes for autism include AMPA 2 (GRIA2) that encodes the GluR2 subunit of the AMPA glutamate receptor, GLRA3 and $G L R B$ that encode glycine receptor subunits $\alpha 3$ and $\beta$ and the Neuropeptide Y receptor encoding genes NPY1R and NPY5R.

\section{Discussion}

This study is the first case report of autism associated with an interstitial deletion on chromosome $4 \mathrm{q}$. Deletion of contiguous genes in the $4 \mathrm{q} 32-4 \mathrm{q} 34$ region could lead to the specific dysmorphic features as well as the behavioral phenotype seen in the subject. Among the deleted genes, potential candidates for autistic disorder are most likely to be those that are abundantly expressed in the brain.

Glutamate receptors are named for the pharmacological substances that influence them. AMPA glutamate receptors are responsive to alpha-amino-3-hydroxy-5-methyl- 
4-isoxazole propionate (AMPA) [13]. Abraham and Bear [14] reported that AMPA receptor mediated neurotransmission plays a key role in several aspects of developmental and adult synaptic plasticity. AMPA glutamate receptors are excitatory ionotropic neurotransmitter receptors. In these the receptor itself forms an ion channel, and binding of the ligand to the receptor is followed by an influx of ions, sodium, potassium or sometimes calcium into the neuronal synapse. AMPA glutamate receptors are composed of four sub-unit types GluR1, GluR2, GluR3 and GluR4. The genes encoding these receptors are named AMPA 1-4 (GRIA1-4). Each GRIA (AMPA) glutamate receptor gene encodes a protein of 900 amino acids and the different sub-units show 70\% amino-acid homology. The $\mathrm{C}$ terminal ends of the GluR sub-units determine their interactions with other synapse associated proteins. AMPA receptors are permeable to $\mathrm{Na}+, \mathrm{K}+$ and to some degree to $\mathrm{Ca}+$. GluR2 receptor sub-units are particularly involved in the control of $\mathrm{Ca}+$ influx [15].

Two different splice forms of each sub-unit occur. Different splice forms predominate in various regions of the brain during adult and fetal life. There are also alterations in the ratio of GluR2 to GluR3 during development of brain. The AMPA glutamate receptors achieve high density in the cerebral cortex, hippocampus, in the basolateral and lateral nuclei of the amygdala, in the caudate, putamen, nucleus accumbens and olfactory bulb. AMPA receptors occur in the pyramidal layer of the hippocampus and in layers II and III of the cerebellar cortex. Levels of GluR2 are particularly high in the cerebellar cortex and in the Bergman glia of the cerebellum [13-15].

Receptors may be composed of identical sub-units or of different sub-units. Mansour et al. [16] reported that heteromeric receptors are made up of no more than two types of sub-units. GluR2 subunit is expressed abundantly in the hippocampal pyramidal neurons and Purkinje cells in the cerebellum [17]. Sans et al. [18] showed that in the pyramidal neurons of the hippocampus the GluR2 subunit is the major determinant of AMPA receptor structure. Furthermore at this site the GluR2 sub-unit plays a major role in receptor trafficking. Since the specific sub-units in the receptor determine the functional properties of the receptor, the relative quantities of specific receptor subunits that are available may be involved in regulating AMPA receptor function. Sans et al. [18] analyzed glutamate receptors in GluR2 knockout mice. In their studies of the hippocampus in mice with reduced or deleted GluR2 sub-units, they demonstrated that GluR2 sub-units play a critical role in the assembly and synaptic expression of the AMPA receptor complex. When GluR2 is present in sufficient amounts, GluR1-GluR3 receptor sub-types are not found. In GluR2+/- mice, GluR2 protein levels are approximately $51 \%$ of normal. In GluR2-/- mice, no GluR2 pro- tein was present. Furthermore, in GluR2+/+ mice, Sans et al. determined that no GluR1/GluR3 receptors occurred. However, in GluR2+/- mice and in GluR2-/- mice, GluR1/ Glur3 receptors were present.

Our patient is GluR2+/- and it is therefore likely that there are more GluR1/GluR3 receptors present in his hippocampus than in control subjects. It is possible that this change contributes to the pathogenesis of his autistic symptoms.

Several investigators have attributed the atypical processing of information in autism to abnormalities in hippocampal functioning. Raymond et al. [19] used the Golgi stain to analyze pyramidal cells in region CA1 and CA2 of the hippocampus. They demonstrated reduced neuronal cell size and decreased dendritic branching in brains from autistic subjects.

The brain regions that have most frequently shown anatomical changes in autism are the hippocampus and the cerebellum [20]. It is interesting to note that Purcell et al. [21] reported that the AMPA receptor density was decreased in the cerebellum of individuals with autism.

Carlsson [22] hypothesized that autism may be a hypoglutamatergic disorder based on pharmacotherapeutic studies in mice. Administration of glutamate antagonists leads to autism-like characteristics including heightened auditory and tactile perception and decreased pain sensitivity. Jamain et al. [23] reported linkage of autism to a $11 \mathrm{cM}$ region on $6 \mathrm{q} 21$, which includes the gene that encodes the ionotropic kainite glutamate receptor subunit GluR6.

Our patient is hemizygous for the genes that encode the Glycine receptor sub-units $\alpha 3$ and $\beta$. Glycine and GABA are the main inhibitory transmitters in the central nervous system. Glycine acts through ionotropic receptors. In addition it modulates NMDA glutamate receptors. The glycine receptor is a glycoprotein composed of 5 subunits. Together the sub-units form glycine gated chloride receptors. The alpha sub-unit binds the glycine ligand. Each receptor is composed of three $\alpha$ and two $\beta$ sub-units. Four different genes encode Glycine receptor $\alpha$ sub-units [13]. Glycine receptors occur in the spinal cord, brainstem and in the hippocampus, amygdala, striatum and cortex. Homomeric glycine receptors composed of a single type of alpha sub-unit are found in embryonic life and in the early post-natal period [24]. Glycine receptor $\alpha 3$ subunits are abundant in the frontal and temporal lobes and in the putamen. Two transcripts are derived from the GLRA3 gene. One is $2.4 \mathrm{~Kb}$, the other is $9 \mathrm{~Kb}$ in size. The precise role of glycine receptors is not understood. Okabe et al. [25] demonstrated that glycinergic membrane responses 
occur early in embryonic neocortical development life in the cortical plate neurons and Cajal Retzius cells. Paton and Richter [26] and Bracci et al. [27] postulated that glycinergic inhibition governs the rhythmic output of mammalian motor systems including the medullary respiratory network. Mutations in the GLRA1 subunit have been shown to result in hyperekplexia characterized by excessive startle reactions to unexpected, particularly auditory stimuli [28]. However, in a subset of families hyperekplexia is not associated with mutations in GLRA1, suggesting that other genes in the glycinergic pathway, including the $\alpha 3$ and $\beta$ subunits of the glycine receptor, may be involved [28]. Increased sensitivity to auditory stimuli is a feature associated with autistic disorder.

There is a growing body of data that confirms that neurogenesis takes place in post-natal and in adult life. The hippocampus is one of the key sites for generation of new neurons after birth. Van Praag [29] and others demonstrated that newly generated post-natal neurons are integrated into hippocampal circuitry. Gould et al. [30] reported that hippocampal neurogenesis is enhanced by learning new skills. Collectively these studies provide evidence that post-natal neurogenesis in the hippocampus plays a role in learning and memory. Aylward et al. [31] reported that there is a reduction in the volume of amygdala and hippocampus in autistic individuals, particularly in relation to total brain volume. They concluded that the histopathology of autism suggests that these volume reductions are related to a reduction in dendritic tree and neuropil development and probably indicate the underdevelopment of the neural connections of limbic structures with other parts of the brain, particularly cerebral cortex.

The subject with autism reported here is hemizygous for genes encoding the neuropeptide $\mathrm{Y}$ receptors NPY1R and NPY5R. Dumont et al. [32] demonstrated that Neuropeptide Y (NPY) affects cognitive function and learning and memory. Thorsell et al. [33] reported impaired spatial learning in transgenic rats that over expressed NPY and demonstrated decreased NPY Y1 receptor binding. Michel et al. [34] reported that in the hippocampus NPY is localized to GABA-ergic interneurons and its activity is mediated through its Y1, Y2 or Y5 receptors. These receptors are coupled to $G$ protein signaling pathways.

Howell and coworkers [35] demonstrated that NPY has a proliferative effect on hippocampal nestin positive neuronal precursor cells and on hippocampal beta tubulin positive neuroblasts. They carried out studies of the hippocampal cells in NPY Y1 receptor knockout mice. Through studies in these mice and through in vitro studies in the presence of selective NPY Y1 receptor agonists and antagonists, Howell et al. [35] demonstrated that the neu- roproliferative effect of NPY in the hippocampus is mediated through the neuropeptide $\mathrm{Y}$ receptor NPY Y1 (NPY1R). They postulate that the effect of NPY on learning and memory may be mediated through NPY neurogenesis.

The distal breakpoint in our subject interrupts the Glycoprotein M6A gene GPM6A. The M6A glycoprotein was first identified in mouse brain by antibody binding assays as a factor that affects the growth of neurites in cultured cerebellar neurons [36]. The human homolog of this gene, GPM6A maps to chromosome $4 \mathrm{q} 34$ in humans and a second family member GPMGB maps to Xp22.2-p22.4 [37]. The human homologs of the murine M6A glycoprotein are yet to be studied thoroughly in terms of function and pathology.

Linkage studies on autism families reported by Yonan et al. [38] and Buxbaum et al. [39] provide further support for location of an autism-determining gene or genes on chromosome 4q. Yonan et al. reported a linkage peak for autism at 94 centimorgans (cM) on chromosome 4q. Buxbaum et al. reported linkage peaks between 104.9 and 126 $\mathrm{cM}$ on $4 \mathrm{q}$. The deletion in our patient lies approximately between 157 to $177 \mathrm{cM}$.

\section{Conclusions}

This case illustrates the importance of carrying out cytogenetic and molecular genetic analysis in subjects with autism. Although there is clear evidence that genetic factors play a role in autism, many genes are likely involved. Identification of autism candidate genes through linkage analysis is hampered by the extreme genetic heterogeneity in autism. Cases of autism in which structural chromosome changes occur are invaluable since they highlight chromosome regions that are the sites of autism candidate genes.

Our molecular genetic analysis of the deletion on chromosome $4 \mathrm{q}$ in the patient described here highlights specific autism candidate genes. It also serves to broaden the spectrum of candidate genes to be considered for analysis in autism. Hemizygous deletion of the AMPA 2 glutamate neurotransmitter receptor gene that encodes sub-unit GluR2 is of interest given the role of glutamate receptors in maintaining structural and functional plasticity of synapses. Hemizygosity for the neuropeptide Y receptor genes NPY1R and NPY5R is of great interest since neuropeptide $\mathrm{Y}$ and its receptors play a role in hippocampal learning and memory. Our patient is also hemizygous for glycine receptor encoding genes GLRA3 and GLRB. Although the precise role of glycinergic receptors is not known, recent data reveal that glycinergic membrane responses occur early in embryonic neocortical development life, in the cortical plate neurons and Cajal Retzius cells. 
To evaluate the significance of the genes we identified as candidates for determining the pathophysiology of autism, it will be necessary to carry out cytogenetic studies, molecular cytogenetic analyses and DNA sequence analysis in other patients with autism.

\section{Competing interests}

None declared.

\section{Authors' contributions}

SR, PF, LM - Patient interview, compilation of patient records

CM - Neuropsychiatric testing

RSE - Neurological evaluation

MB - Dysmorphology evaluation

AW - Microsatellite polymorphic marker analysis

MS, SR, MH - Preparation of BACs and molecular cytogenetic studies

SR, MS, MH, PF - Manuscript preparation

MAS - Principal investigator

\section{Acknowledgements}

We are grateful to the patient and family reported here for participating in our research and for consenting to publication of our findings. This research was supported by grant POIHD 35458-0IAI NICHD (M.A Spence, Principal Investigator). The University of California, Irvine is one of ten NIH NICHD NINDS funded sites in the CPEA network for research on autism.

\section{References}

I. Bailey A, Le Couteur A, Gottesman I, Bolton P, Simonoff E, Yuzda E, Rutter M: Autism as a strongly genetic disorder: evidence from a British twin study. Psychol Med 1995, 25:63-77.

2. Baird TD, August GJ: Familial heterogeneity in infantile autism. J Autism Dev Disord 1985, 15:315-321.

3. Bolton P, Macdonald H, Pickles A, Rios P, Goode S, Crowson M, Bailey $A$, Rutter M: A case-control family history study of autism. J Child Psychol Psychiatry 1994, 35:877-900.

4. APA: Diagnostic and Statistical Manual of Mental Disorders. 3rd edition. Washington D.C., American Psychiatric Association; 1994.

5. Lord C, Risi S, Lambrecht L, Cook E. H., Jr., Leventhal BL, DiLavore PC, Pickles A, Rutter M: The autism diagnostic observation schedule-generic: a standard measure of social and communication deficits associated with the spectrum of autism. J Autism Dev Disord 2000, 30:205-223.

6. Lord C, Rutter M, Le Couteur A: Autism Diagnostic InterviewRevised: a revised version of a diagnostic interview for caregivers of individuals with possible pervasive developmental disorders. J Autism Dev Disord 1994, 24:659-685.

7. Thorndike Robert Ladd, Hagen EP, Sattler JM: The Stanford-Binet Intelligence Scale: Guide for Administering and Scoring. 4th edition. Chicago, The Riverside Publishing Company; 1986.

8. Dunn LM, Dunn L: Peabody Picture Vocabulary Test. 3rd edition. Circle Pines, American Guidance Service; 1997.
9. National Center for Biotechnology Information (NCBI) Website [http://www.ncbi.nlm.nih.gov]

10. Marshfield Clinic [http://www.marshfieldclinic.org/genetics]

II. Centre d'Etude du Polymorphisme Humain (CEPH) Database [http://www.cephb.fr]

12. National Center for Biotechnology Information (NCBI) BLAST [http://www.ncbi.nlm.nih.gov/BLAST]

13. von Bohlen und Halbach $O$, Dermietzel R: Neurotransmitters and Neuromodulators: Handbook of Receptors and Biological Effects. Weinheim, Wiley-VCH; 2002.

14. Abraham WC, Bear MF: Metaplasticity: the plasticity of synaptic plasticity. Trends Neurosci 1996, 19:126-I30.

15. Tanaka H, Grooms SY, Bennett MV, Zukin RS: The AMPAR subunit GluR2: still front and center-stage. Brain Res 2000, 886: 190-207.

16. Mansour M, Nagarajan N, Nehring RB, Clements JD, Rosenmund C: Heteromeric AMPA receptors assemble with a preferred subunit stoichiometry and spatial arrangement. Neuron 200 I, 32:84I-853.

17. Breese CR, Logel J, Adams C, Leonard SS: Regional gene expression of the glutamate receptor subtypes GluRI, GluR2, and GluR3 in human postmortem brain. J Mol Neurosci 1996, 7:277-289.

18. Sans N, Vissel B, Petralia RS, Wang YX, Chang K, Royle GA, Wang CY, O'Gorman S, Heinemann SF, Wenthold RJ: Aberrant formation of glutamate receptor complexes in hippocampal neurons of mice lacking the GluR2 AMPA receptor subunit. J Neurosci 2003, 23:9367-9373.

19. Raymond GV, Bauman ML, Kemper TL: Hippocampus in autism: a Golgi analysis. Acta Neuropathol (Berl) 1996, 91 : I I7-II 9.

20. Bauman ML, Kemper TL: The neuropathology of the autism spectrum disorders: what have we learned? Novartis Found Symp 2003, 25 I: I I 2-22; discussion I22-8, 28I-97.

2I. Purcell AE, Jeon OH, Zimmerman AW, Blue ME, Pevsner J: Postmortem brain abnormalities of the glutamate neurotransmitter system in autism. Neurology 2001, 57:1618-1628.

22. Carlsson ML: Hypothesis: is infantile autism a hypoglutamatergic disorder? Relevance of glutamate - serotonin interactions for pharmacotherapy. J Neural Transm 1998, 105:525-535.

23. Jamain S, Betancur C, Quach H, Philippe A, Fellous M, Giros B, Gillberg $C$, Leboyer $M$, Bourgeron T: Linkage and association of the glutamate receptor 6 gene with autism. Mol Psychiatry 2002, 7:302-310.

24. Chen Z, Dillon GH, Huang R: Molecular determinants of proton modulation of glycine receptors. / Biol Chem 2004, 279:876-883.

25. Okabe A, Kilb W, Shimizu-Okabe C, Hanganu IL, Fukuda A, Luhmann $\mathrm{HJ}$ : Homogenous glycine receptor expression in cortical plate neurons and cajal-retzius cells of neonatal rat cerebral cortex. Neuroscience 2004, I 23:715-724.

26. Paton JF, Richter DW: Role of fast inhibitory synaptic mechanisms in respiratory rhythm generation in the maturing mouse. J Physiol 1995, 484 ( Pt 2):505-52I.

27. Bracci E, Ballerini L, Nistri A: Spontaneous rhythmic bursts induced by pharmacological block of inhibition in lumbar motoneurons of the neonatal rat spinal cord. J Neurophysiol 1996, 75:640-647.

28. Vergouwe MN, Tijssen MA, Shiang R, van Dijk JG, al Shahwan S, Ophoff RA, Frants RR: Hyperekplexia-like syndromes without mutations in the GLRAI gene. Clin Neurol Neurosurg 1997, 99:172-178

29. van Praag H, Schinder AF, Christie BR, Toni N, Palmer TD, Gage FH: Functional neurogenesis in the adult hippocampus. Nature 2002, 4I 5: 1030-1034.

30. Gould E, Reeves AJ, Graziano MS, Gross CG: Neurogenesis in the neocortex of adult primates. Science 1999, 286:548-552.

31. Aylward EH, Minshew NJ, Goldstein G, Honeycutt NA, Augustine $A M$, Yates KO, Barta PE, Pearlson GD: MRI volumes of amygdala and hippocampus in non-mentally retarded autistic adolescents and adults. Neurology 1999, 53:2 | 45-2 I50.

32. Dumont Y, Martel JC, Fournier A, St-Pierre S, Quirion R: Neuropeptide $Y$ and neuropeptide $Y$ receptor subtypes in brain and peripheral tissues. Prog Neurobiol 1992, 38:125-167.

33. Thorsell A, Michalkiewicz M, Dumont $Y$, Quirion R, Caberlotto L, Rimondini $R$, Mathe AA, Heilig M: Behavioral insensitivity to restraint stress, absent fear suppression of behavior and impaired spatial learning in transgenic rats with hippocam- 
pal neuropeptide $\mathbf{Y}$ overexpression. Proc Natl Acad Sci U S A 2000, 97: I 2852-12857.

34. Michel MC, Beck-Sickinger A, Cox H, Doods HN, Herzog H, Larhammar D, Quirion R, Schwartz T, Westfall T: XVI. International Union of Pharmacology recommendations for the nomenclature of neuropeptide $Y$, peptide $Y Y$, and pancreatic polypeptide receptors. Pharmacol Rev 1998, 50:143-150.

35. Howell OW, Scharfman HE, Herzog H, Sundstrom LE, Beck-Sickinger A, Gray WP: Neuropeptide $\mathbf{Y}$ is neuroproliferative for postnatal hippocampal precursor cells. I Neurochem 2003, 86:646-659.

36. Yan Y, Lagenaur C, Narayanan V: Molecular cloning of M6: identification of a PLP/DM20 gene family. Neuron 1993, I I:423-431.

37. Olinsky S, Loop BT, DeKosky A, Ripepi B, Weng W, Cummins J, Wenger SL, Yan Y, Lagenaur C, Narayanan V: Chromosomal mapping of the human M6 genes. Genomics 1996, 33:532-536.

38. Yonan AL, Alarcon M, Cheng R, Magnusson PK, Spence SJ, Palmer AA, Grunn A, Juo SH, Terwilliger JD, Liu J, Cantor RM, Geschwind DH, Gilliam TC: A genomewide screen of $\mathbf{3 4 5}$ families for autismsusceptibility loci. Am J Hum Genet 2003, 73:886-897.

39. Buxbaum JD, Silverman J, Keddache M, Smith CJ, Hollander E, Ramoz N, Reichert JG: Linkage analysis for autism in a subset families with obsessive-compulsive behaviors: evidence for an autism susceptibility gene on chromosome $I$ and further support for susceptibility genes on chromosome 6 and 19. Mol Psychiatry 2004, 9: 144-150.

\section{Pre-publication history}

The pre-publication history for this paper can be accessed here:

http://www.biomedcentral.com/1471-2350/5/10/prepub

Publish with Biomed Central and every scientist can read your work free of charge

"BioMed Central will be the most significant development for disseminating the results of biomedical research in our lifetime. "

Sir Paul Nurse, Cancer Research UK

Your research papers will be:

- available free of charge to the entire biomedical community

- peer reviewed and published immediately upon acceptance

- cited in PubMed and archived on PubMed Central

- yours - you keep the copyright 